\title{
GURU DALAM PENINGKATAN PROFESIONALISME, AGEN PERUBAHAN DAN REVOLUSI INDUSTRI 4.0
}

\author{
Oleh \\ I Made Sedana \\ STAHN Mpu Kuturan Singaraja \\ made_sedana23@yahoo.com
}

diterima 23 Mei 2019, direvisi 21 Agustus 2019, diterbitkan 31 Agustus 2019

\begin{abstract}
The progress of science and technology in the era of globalization which has now led to the era of industrial revolution 4.0 brings the effect of extraordinary changes to the pattern of life of humanity in this hemisphere. Teachers as educators are implementers of the education profession, in carrying out their professions there are several requirements that must be met by a teacher in order to have qualifications and credibility in the field of education. This is a condition for the realization of professional teachers, namely having overall competency both in the field of education and learning methodology as well as the substance of the scientific field. Teachers will become a developing profession when constantly changing themselves, because practical education will continue in different situations and times. Improving the ability of teachers to carry out their profession should not be passive but must be proactive, do not wait for opportunities but seek opportunities.
\end{abstract}

\section{Keywords: revolution 4.0, education, teachers, profession}

\section{PENDAHULUAN}

Kemajuan ilmu pengetahuan dan teknologi di era globalisasi yang kini telah menuju era revolusi industri 4.0 (desrupsi) membawa pengaruh perubahan yang luar biasa terhadap pola kehidupan umat manusia di belahan bumi ini. Terjadi transformasi budaya pada seluruh sendi kehidupan masyarakat, sehingga perubahan demi perubahan terus terjadi baik pada ranah kompleks ide, kompleks kelakuan berpola, dan kompleks sistem teknologi
(Koentjaraningrat, 1982; Sztompka. 2004). Disamping itu era globalisasi yang ditandai dengan transformasi informasi-tehnologi (IT) mengkondisi proses-proses kehidupan di berbagai bidang berada pada arus high competition yang begitu cepat dan mendasar dengan membawa beragam resiko kehidupan (Giddens, Anthony 2001). Perubahan fenomena kehidupan terkini tersebut, ditangkap oleh pemerintah Indonesia dengan melakukan perubahan pada orientasi pembangunan nasional, yaitu dari lebih 
menekankan pada orientasi economic recource development, bergeser untuk mulai memperhatikan ke human resource development. Khususnya dibidang pendidikan pemerintah telah menyusun Undang Undang No. 20 tahun 2003 tentang SISDIKNAS, yang kemudian dijabarkan dalam PP No. 19 tahun 2005 tentang Standar Nasional Pendidikan (SNP). Dalam rangka meningkatkan kualitas guru dan dosen, disusun pula Undang Undang No. 14 tahun 2005 tenang Guru dan Dosen, selanjutnya dikeluarkan Permendiknas No. 16 tahun 2007 tentang standar kualifikasi akademik dan kompetensi guru, dan beberapa produk hukum lainnya. yang berkaitan dengan upaya pemerintah dalam mereformasi pembangunan bidang pendidikan. Semua produk hukum yang berkaitan dengan pendidikan tersebut pada dasarnya merupakan realitas teoritik (das sollen)tentang komitmen pemerintah untuk memajukan sistem pendidikan nasional.

Persoalannya adalah, apa yang tersaji dalam realitas sehari-hari di lapangan (das sain), khususnya tentang kemampuan profesional guru masih belum terberdayakan secara maksimal, sehingga dari aspek pendidik banyak kendala yang muncul di lapangan dalam mengimplementasikan beragam peraturan tersebut. Semenjak dua belas tahun terakhir (sejak 2006) pemerintah telah memulai melakukan program sertifikasi guru, dan salah satu tujuannya adalah untuk meningkatkan kualitas profesional guru. Uraian tersebut di atas menunjukkan bahwa proses pembangunan pendidikan di Indonesia masih dihadapkan pada persoalan yaitu, adanya kesenjangan antara realitas teoritik (das sollen) dengan realitas emipirik (das sein) dalam proses kualitas layanan pendidikan di setiap satuan pendidikan.

Di sisi lain, tuntutan dan harapan masyarakat yang terus meningkat dan berubah membuat guru makin ditantang. Perubahan yang terjadi dalam masyarakat melahirkan tuntutan-tuntutan baru terhadap peran (Role Expectation) yang seharusnya dimainkan oleh guru. Akibatnya, setiap penambahan kemampuan guru seiring sertifikasi selalu berpacu dengan meningkatnya kemampuan dan harapan masyarakat tersebut yang kadang-kadang lebih cepat dari kemampuan guru untuk memenuhinya. Masalah terjadi apabila harapan atas peran guru bertambah, sementara kemampuan giru memenuhinya terbatas. Bila dimasa lalu guru menjadi sumber utama belajar siswa untuk menjawab ketidaktahuan siswa, sekarang bukan lagi. Di rumah tersedia radio, televisi, surat kabar, bahkan komputer dan internet. Tidak berlebihan bila dikatakan bahwa dengan pengecualian pedesaan barisan depan dalam irama perubahan masyarakat sebagaimana dipercayai di masa lalu, melainkan pengikut perubahan masyarakat yang bergerak jauh di depan mereka. Dalam situasi demikian, tidak mudah menegakkan profesi keguruan dalam tantangan sebagai penggerka perubahan, sebagaiman harapan masyarakat dan tantangan era disrupsi yang tidak terbendung ini .Jadi, betapa peliknya problematik dan betapa beratnya tantangan yang dihadapi profesi keguruan.

\section{PEMBAHASAN}

\section{1) Konsepsi Profesionalisme Guru}

Dalam dunia pendidikan tentu tidak lepas dari adanya pesan seorang guru yang menjadi inti penting dalam proses pembelajaran. Guru adalah sosok pelaksana dalam kegiatan pembelajaran yang akan mengerahkan perkembangan peserta didik dalam perubahan kearah positif. Guru harus melakukan tugasnya secara profesional artinya adalah guru harus memiliki gelar atau amanat sesuai kriteria guru. Sedangkan profesi guru adalah suatu jabatan atau pekerjaan dibidang pendidikan, mengajar peserta didik, dalam UU No. 14 Tahun 2005, dengan tugas utama mendidik, mengajar, membimbing, mengarahkan, melatih, menilai, dan mengevaluasi peserta didik.

Menurut Muchtar Lutfi dalam Fahri (2013:2) menyebutkan kriteria seorang guru yang disebut memiliki profesi yaitu:

a. Profesi harus mengandung keahlian, ini artinya profesi harus diikuti 
dengan adanya sebuah keahlian yang khusus untuk profesi tersebut.

b. Profesi dipilih karena panggilan hidup dan dijalani dengan penuh waktu

c. Profesi memiliki teori-teori yang baku secara universal, artinya profesi tersebut harus dijalani menurut aturan yang jelas, dikenal umum,teorinya terbuka.

d. Profesi adalah untuk masyarakat, bukan untuk diri sendiri, ini artinya profesi tidak dapat lepas dari pengabdian kepada sesama dan masyarakat secara umum.

e. Profesi harus dilengkapi dengan kecakapan diagnosis dan kompetensi aplikatif ini diperlukan untuk dapat meyakinkan peran profesi tersebut.

f. Pemegang profesi memiliki otonom dalam melakukan profesinya, yaitu profesinya dapat dinilai oleh rekan seprofesinya.

g. Profesi memiliki kode etik yang disebut sebagai kode etik profesi

h. Profesi harus memiliki klien yang jelas yaitu orang yang membutuhkan layanan atau jasa dari seorang profesi.

Dari ciri-ciri profesionalitas itu jelas bahwa guru tidak bisa datang dari mana saja tanpa melalui sistem pendidikan profesi dan seleksi yang baik. Dengan demikian, pekerjaan guru tidak bisa lagi dijadikan sebagai upaya sambilan, atau pekerjaan sebagai moonlighter.Guru yang profesional harus memiliki integritas, ilmu pengetahuan yang memadai sesuai dengan bidangnya, watak yang terpuji, kompetensi, dan bahkan harus mengikuti pendidikan yang baik, bukan sekedar mengikuti pelatihan semata (educated, bukan hanya trained). Dari karakteristik yang ia miliki itu akhirnya baru ada pengakuan dan penghargaan dari masyarakat.

Oleh karena itu, sertifikasi guru di negeri ini, yang saat ini masih hangat menjadi wacana dan diskusi publik, pada akhirnya harus berujung pada pengakuan dan penghargaan masyarakat luas akan profesionalisme guru itu sendiri. Hal ini terjadi jika setelah dikeluarkan sertifikat, bagi guru yang mendapatkan memang benarbenar menunjukkan kinerja profesional yang mampu mengubah kualitas pembelajaran dari konvensional, rutin, mekanistis, menjadi sebuah proses yang dialogis, dinamik, demokratik, dan memberdayakan peserta didik. Rahdiyanta (2014:375).

Jika profesionalisme guru dilihat dari kaca mata Undang-undang Guru dan Dosen (UU No. 14 Tahun 2005), jelas undangundang itu mensyaratkan guru untuk memiliki kualifikasi, kompetensi, dan sertifikasi. Pasal 8 UU No. 14 Tahun 2005 menyebutkan : "Guru wajib memiliki kualifikasi akademik, kompetensi, sertifikasi pendidik, sehat jasmani dan rohani, serta memiliki kemampuan untuk mewujudkan tujuan pendidikan nasional". Selanjutnya, kompetensi yang harus dimiliki oleh seorang guru yang profesional, menurut Pasal 10 ayat (1) meliputi kompetensi pedagogik, kompetensi kepribadian, kompetensi sosial, dan kompetensi profesional yang diperoleh melalui pendidikan profesi.

Sementara itu Suparno (2004:47-50) menegaskan bahwa guru profesionalitu adalah memiliki kepribadian yang utuh,yaitu : (1) guru harus bermoral dan beriman; hal ini penting karena salah satu tugas guru adalah membantu anak didik bertaqwa dan berimanserta menjadi anak yang baik, (2) guru harus mempunyai aktualisasi diri yang tinggi. Aktualisasi diri disini adalah sikap bertanggungjawab, (3) guru maтри berkomunikasi dengan baik. Komunikasi yang baik akan membantu proses pembelajaran dan pendidikan terutama pada level dasar dan menengah. Banyak kasus, guru yang memiliki pengetahuan yang luas, tetapi tidak mampu berkomunikasi dengan siswa (anak didik) dengan baik, (4) guru harus disiplin. Setiap aktivitas hendaknya menerapkan disiplin yang tinggi, karena kunci sukses salah satunya adalah disiplin, dan kita sangat mudah diucapkan, dilaksanakan sangat sulit, (5) guru dituntut untuk belajar terus agar pengetahuannya 
tetap segar. Guru tidak boleh berhenti belajar.

Lebih lanjut, Dantes (2017: 201-202) menegaskan bahwa perilaku seorang guru sebagai pekerja profesional secara garis besar semestinya mencerminkan tiga hal pokok yakni: (1) thoughtfullness, (2) adaptability, dan (3) cohesiveness. Pada dimensi pertama (thoughtfullness), perilaku seorang guru semestinya mencerminkan kepemilikan landasan keilmuan dan keterampilan yang memadai yang dicapainya dalam suatu proses panjang baik selama berada di dalam pendidikan prajabatan maupun berbagai tambahan pengalaman yang didapatkannya selama berada di dalam jabatan. Dalam konteks ini seorang guru profesional harus senantiasa memutahirkan ilmunya melalui penambahan pengetahuan dan memperkaya pengalamannya. Dimensi yang kedua (adaptability) menyiratkan makna bahwa guru profesioanl di dalam melaksanakan tugasnya akan senantiasa melakukan penyesuaian teknis situasional dan kondisional sesuai tuntutan situasi dan kondisi, dengan tetap berorientasi pada usaha tercapainya "disired out-comes". Atau paling tidak penyesuaian dapat dilakukan dalam bingkai pemikiran, bahwa itu semua dilakukan demi untuk lebih mendekatkan antara "actual out-comes" dengan "disired out-comes". Dimensi ketiga (cohesiveness) mengandung makna bahwa di dalam melakukan pekerjaannya seorang guru profesional akan menyikapi pekerjaannya dengan penuh dedikasi dengan senantiasa berpedoman pada kaidah-kaidah teknis, prosedural, dan kaidah filosofi sehingga menjadikan unjuk kerjanya taat azas dan tepat makna yang ditujukan sebgai layanan yang arif bagi kemaslahatan orang lain.

\section{2) Peran Guru Sebagai Agent of Change}

Sebagaimana yang telah disinggung di atas, bahwa kondisi kualitas guru di Indonesia secara makro masih belum terberdayakan secara maksimal, dan diantara faktor kunci penyebabnya adalah kondisi mentalitas, motivasi atau dorongon internal guru untuk terus belajar, berinovasi dalam pembelajaran dan terus mengikuti perkembangan Iptek terkini masih relatif rendah (Oemar, H., 2002; Tilaar, 2002; Wahab, A.A., 2007). Beberapa langkah strategis yang dapat dilakukan dalam meningkatkan peran guru sebagai agen perubahan (agent of change) pembelajaran siswa di kelas antara lain: Pertama, membangun kualitas mentalitas positif guru melalui kegiatan pelatihan 'motivasi berprestasi' dan sejenisnya secara periodik, misalnya pembinaan dan pelatihan ESQ.

Meskipun setiap guru secara teoritik telah mengetahui sebagian teori-teori psikologi pembelajaran, dia tetap memerlukan penyegaran orientasi dan wawasan hidup prospektif dari para pakar psikologi atau para motivator dalam menghadapi beragam persoalan pekerjaan sebagai pendidik. Dalam hal ini fokus pelatihan lebih ditekankan pada upaya membangun konsistensi diri sebagai pendidik sepanjang karir profesinya untuk mengembangkan tentang: (a) prinsip selalu belajar (learning principle); (b) prinsip kebutuhan untuk berprestasi (need achievement principle); (c) prinsip kepemimpinan (leadership principle); prinsip orientasi hidup ke depan (vision principle); dan (d) prinsip menjadi pencerah dalam kehidupan kelompok (well organized principle) (Agustian, A.G. 2005; Seligman, M. 2005). Ketika lima prinsip tersebut terinternalisasi dengan baik pada diri setiap guru, maka guru tersebut akan mampu bertindak sebagai agent of change pembelajaran peserta didik, baik pada aspek emosional, kepribadian dan pengetahuanketrampilan peserta didik. Demikian juga sebaliknya, ketika kelima prinsip tersebut tidak menyatu dan tidak berkembang pada diri setiap guru, maka kehadiran guru di kelas hakikatnya kurang berfungsi dalam menyiapkan peserta didik untuk menghadapi beragam tantangan hidup di era globalisasi.

Kedua, menyikapi kondisi guru yang masih belum memahami beragam inovasi pembelajaran dan arti pentingnya pemanfaatan kemajuan teknologi pembelajaran, maka strategi yang dapat 
dilakukan adalah setiap satuan pendidikan harus mempunyai 'tim ahli inovasi pembelajaran'. Beberapa aktivitas yang dapat dilakukan oleh tim ahli inovasi pembelajaran dalam meningkatkan kualitas guru adalah: (a) melakukan diskusi kolegial tentang pengembangan penguasaan konsepkonsep keilmuan dan perkembangan teknologi terkini; (b) melakukan penyusunan soal-soal sesuai dengan standar kompetensi kelulusan BSNP; (c) melakukan penyusunan bahan ajar atau modul dan melakukan pelatihan penggunaan multi media berbasisi IT; (d) melakukan kegiatan penelitian tindakan kelas; (e) melibatkan guru dalam proses evaluasi diri sekolah (school self evaluation); dan (f) memberikan masukan atau diskusi kolegial tentang penerapan metode pembelajaran yang menegakkan pilar-pilar pembelajaran, yaitu: learning to know (belajar mengetahui), learning to do (belajar berbuat), learning to life together (belajar hidup bersama), dan learning to be (belajar menjadi seseorang) (Djohar, 1999). Ketika "tim inovasi pembelajaran" di setiap satuan pendidikan mampu melaksanakan keenam fungsi tersebut dengan baik dalam pemberdayaan kemampuan guru, maka setiap guru diasumsikan mampu berperan sebagai agent of change pembelajaran siswa di sekolah.

Ketiga, membangun mentalitas kerjasama sebagai team work yang kokoh. Semua guru pada satuan pendidikan dalam proses layanan pendidikan harus menyatu bagaikan satu bangunan kokoh (kesatuan sistem). Proses interaksi dissosiatif sesama pendidik dalam pemberian layanan pendidikan harus diminimalisir (Usman, M.U., 2000; Sanjaya, W. 2007). Oleh karena itu, dalam konteks pemberian layanan pembelajaran di satuan pendidikan yang berkualitas, seharunya setiap guru senantiasa belajar untuk memajukan satuan pendidikannya melalui enam konsep yaitu: (1) system thinking; (2) mental models; (3) personal mastery; (4) team learning and teaching; (5) shared vision; dan (6) dialog (Peter dalam Soetrisno, 2002). Dalam membangun kualitas mental guru sebagai suatu team work untuk melaksanakan keenam konsep tersebut, kedudukan dan peran kepala sekolah adalah sangat sentral. Kepala sekolah harus mampu memainkan peran baru (new rules), keterampilan baru (new skills), dan mampu mengaplikasikan sarana baru dari permasalahan yang timbul (new tools). Kepala sekolah harus: (a) berperan sebagai perancang (designer) kebijakan strategis terhadap aplikasi keenam konsep tersebut; (b) berfikir integral dalam mencermati tantangan pendidikan ke depan (visioner).; (c) mampu membangkitkan learning organization; (d) mendorong setiap guru untuk mengembangkan potensi profesinya secara maksimal; dan (e) terbuka pada kritik dan saran yang konstruktif; transparan dan tanggungjawab dalam pengelolaan sumber daya sekolah (Arifin, 2007). Ketika guru pada setiap satuan pendidikan mampu menjalin kerjasama dalam mewujudkan keenam konsep tersebut, diasumsikan mereka akan mampu berperan sebagai agent of change pembelajaran siswa di sekolah dengan baik. Pakar psikologi Seligman, M. (2005), mengatakan 'ketika individu mampu membangun mentalitas positif, misalnya sanggup menjalin komunikasi humanis di setiap kehidupan kelompok, maka individu tersebut akan mampu meraih kebahagiaan dan keberhasilan puncak dalam hidupnya'.

Keempat. Dinas Pendidikan Kabupaten/Kota/Provinsi, melalui pengawas sekolah terus melakukan pemantauan atau pembinaan terhadap kinerja guru dalam mengimplementasikan empat kompetensi dasar guru profesional. Ada beberapa persyaratan yang harus dimiliki oleh pengawas dalam proses pembinaan kinerja profesional guru agar mampu menjadi salah satu agent of change pembelajaran di sekolah, yaitu sosok pribadi seorang pengawas sebagai pembina kinerja guru profesional harus betul-betul berkualitas, antara lain: (a) seorang pengawas harus paham secara teoritis dan aplikatif tentang beragam teori psikologi pembelajaran; (b) seorang pengawas harus berwawasan integral, demokratik, visioner dan 
mempunyai keunggulan IESQ; (c) seorang pengawas harus punya kemampuan multi, baik menyangkut disiplin keilmuan tertentu, managerial, komunikator/ motivator, dan humanis; (d) seorang pengawas harus menguasai secara konseptual dan aplikatif tentang research pendidikan dengan beragam strategi atau pendekatan research; dan kemampuan lainnya sesuai dengan statusnya sebagai pengawas sekolah. Diantara langkah yang dapat dilakukan pengawas dalam proses pembinaan kualitas profesional guru sebagai agen perubahan pembelajaran di kelas antara lain: (a) membuat instrumen pemantauan kinerja guru profesional, yang memuat empat standar kompetensi (pedagogik, kepribadian, sosial dan profesional) dan masing-masing kompetensi tersebut dijabarkan secara rinci ke dalam beberapa indikator yang terukur. Instrumen tersebut harus disosialisasikan sejak dini pada semua guru untuk dipahami dan dilaksanakan; (b) pelaksanaan pemantauan instrumen kinerja guru profesional tersebut dilakukan secara 'silang proporsional', yang melibatkan pengawas, kepala sekolah dan teman sejawat (guru) serta peserta didik (siswa); dan (c) pada akhir tahun pelajaran dilakukan evaluasi yang melibatkan pengawas, kepala sekolah dan guru yang bersangkutan secara 'bijak', artinya baik pengawas, kepala sekolah maupun guru sama-sama melakukan refleksi atau instropeksi tentang optimalisasi kinerja sesuai dengan instrumen standar kompetensi yang telah disusun. Ketika proses pembinaan kualitas kinerja guru berjalan dengan baik, kemudian diikuti dengan peningkatan kualitas kinerja guru berdasarkan instrumeninstrumen kompetensi profesional, maka diasumsikan guru tersebut akan mampu berperan dalam peningkatan kualitas pembelajaran siswa di kelas (Nasution, 2006; Wahab, A.A., 2007; Hamzah.B.U., 2008), hal ini secara otomatis menunjukkan bahwa guru mampu berperan secara positif sebagai salah satu agent of change pembelajaran di sekolah.

Kelima, dalam rangka memudahkan aktivitas guru untuk mewujudkan beragam kompetensi profesinya, maka pemerintah dan warga masyarakat harus tetap punya komitmen dalam penyediaan sarana dan prasarana pembelajaran dengan baik, karena ketersediaan sarana dan prasarana pembelajaran secara baik akan mampu meningkatkan kualitas proses pembelajaran siswa di sekolah (Atmadi, ed., 2000; Supriadi, D. 2004). Disamping penyediaan sarana dan prasarana pembelajaran di sekolah secara baik dan lengkap, pemerintah harus tetap konsisten dalam mengupayakan peningkatan kualitas kesejahteraan guru. Untuk merealisaikan dua hal tersebut pemerintah melalui Menteri Pendidikan dan Kebudayaan telah mengeluarkan: (a) Permendiknas Nomor 24 Tahun 2007 tentang Standar Sarana dan Prasarana; (b) Permendikbud Nomor 37 Tahun 2017 tentang Sertifikasi bagi guru dalam jabatan; (b) Permendiknas Nomor 40 tahun 2007, tentang Sertifikasi guru dalam jabatan melalui jalur pendidikan. Ketika sarana dan prasarana pembelajaran tersedia dengan baik, kesejahteraan guru terjamin dan diikuti dengan tumbuhnya sikap mental positif pada diri setiap guru sebagaimana yang telah diuraikan di atas, maka diasumsikan guru akan mampu meningkatkan kualitas profesionalnya (Soetjipto dan Kosasi, 1999; Usman, M.U., 2000), sehingga guru akan mampu berperan sebagai agen perubahan (agent of change) pembelajaran siswa di sekolah.Sebagaimana yang telah diurakan di atas, pada hakikatnya potret seorang guru yang mampu berperan aktif sebagai agen perubahan pembelajaran siswa di kelas, antara lain: (a) mempunyai wawasan yang cukup luas tentang beragam teori psikologi perkembangan atau teori pembelajaran, dan mampu menerapkan secara 'bijak' dalam proses pembelajaran di kelas; (b) mempunyai sikap mental positif terhadap perkembangan Iptek dan selalu berusaha mewujudkan proses pembelajaran di kelas dengan nuansa demokratik, humanis dan multikultural; (c) selalu menjadi contoh teladan terbaik bagi anak dalam segala pola aktivitas hidupnya, baik menyangkut aspek mentalitas, aspek pola prilaku sehari-hari dan pola berpakaian; 
(d) selalu melakukan pemantauan perkembangan hasil belajar siswa dengan menggunakan sistem evaluasi yang baik dan integral yang menyangkut tujuh aspek yaitu: penilaian unjuk kerja (performance), penilaian sikap (afektif), penilaian tertulis (paper and pencil test), penilaian proyek, penilaian produk, penilaian melalui kumpulan hasil karya siswa (portofolio) dan penilaian diri (self assessment); dan (e) selalu berusaha meningkatkan kualitas diri dalam membuat karya tulis ilmiah yang berkaitan langsung dengan inovasi pembelajaran (Arifin, 2009).

\section{3) Tantangan Guru di Era Revolusi Industri 4.0}

Fenomena global tidak bisa kita abaikan begitu saja dalam mengembangkan profesionalisme para guru pada saat ini dan di masa mendatang. Hal ini karena berbagai fenomena global berpengaruh secara signifikan terhadap proses pembelajaran di sekolah. Lebih jauh lagi fenomena global akan berpengaruh juga pada bagaimana masyarakat memiliki standar hidup, gaya hidup, pola interaksi satu sama lain, dan pola migrasi pekerjaan secara maya begitu mudahnya dari satu negara ke negara lain tanpa mengenal batas-batas negara secara teritorial maupun politis. Ini semua pada akhirnya akan meminta para guru untuk mempersiapkan para peserta didiknya menjadi lebih memiliki daya nalar yang tinggi, kreativitas yang baik, dan juga kemampuan untuk melakukan jejaring sistem kerja yang fleksibel terhadap berbagai perubahan global. Mengapa guru harus mempersiapkan hal itu? Karena penelitiannya Bank Dunia menunjukkan bahwa kekuatan suatu negara ditentukan oleh faktor-faktor : (1) innovation and creativity (45\%); (2) networking (25\%); technology $(20 \%)$; dan natural resources (10\%). Fenomena global saat ini ditandai oleh munculnya berbagai wacana kesadaran dalam berbagai aspek kehidupan bernegara dan berbangsa seperti:

1. Ketergantungan pada Iptek (ICT, Bio-teknologi, Nano teknologi);
2. Perdagangan bebas;

3. Fenomena kekuatan global (Speed, Connectivity, dan Intangible);

4. Demokratisasi;

5. HAM (Hak Asasi Manusia);

6. Lingkungan hidup;

7. Kesetaraan gender; dan

8. Multikulturalisme.

Dalam praksis pembelajaran, fenomena global seperti tersebut di atas perlu diperhatikan oleh guru. Bahkan tema-tema pembelajaran harus pula mengadopsi dan mengadaptasi secara terintegrasi arah dan semangat fenomena global itu. Dari fenomena global itu memang ada yang menjadi prasyarat bagi proses pembelajaran di kelas, tetapi ada pula yang menjadi variabel yang harus direspon dalam kegiatan pembelajaran agar materi ajar yang dikembangkan memiliki relevansi yang tinggi.

Sebagai contoh, misalnya, persoalan demokratisasi yang saat ini menjadi kecenderungan yang kuat secara global, perlu diperhatikan guru dalam setiap pengambilan keputusan dalam mengelola kelas. Oleh karena itu, memiliki sikap demokratis adalah merupakan prasyarat yang penting bagi guru yang profesional di era global. Begitu juga ketergantungan pada Iptek, misalnya, jelas merupakan fenomena global yang harus direspons guru dalam proses belajar-mengajar dalam arti luas agar proses pembelajaran bisa berjalan efisien, relevan, dan selalu aktual. Tanpa merespons fenomena global itu, semua guru akan tergelincir pada unjuk kerja yang tidak kontekstual, sehingga pembelajaran yang terjadi tidak akan mampu membekali para peserta didik untuk memiliki kompetensi yang relevan dengan tuntutan era revolusi industri 4.0.

Begitu juga kita mengambil persoalan multikulturalisme, yang saat ini dengan gencarnya telah menjadi gerakan dan kekuatan global, maka guru harus memahaminya dan memiliki perspektif yang baik dan positif. Jika dalam proses pembelajaran guru mau dan mampu menyerap substansi multikulturalisme, dan 
kemudian mampu mengintegrasikan ke dalam setiap pilihan metode dan pendekatan pembelajaran secara pedagogis, dapat dipastikan guru yang bersangkutan akan mampu menanamkan pemahaman dan arti penting pluralisme, toleransi, empati, dalam kehidupan global kepada para peserta didik secara efektif.

Era global yang sering disebut sebagai "era disrupsi" seperti saat ini tentu memiliki pengaruh yang signifikan terhadap bagaimana pola pembelajaran yang mampu memberdayakan para peserta didik. Hal ini terjadi akibat perkembangan ICT (information and communication technology) yang sangat pesat dari hari ke hari. Dengan perkembangan ICT yang pesat itu guru yang profesional harus mampu menangkapnya sebagai peluang yang baik bagi pengembangan proses belajar para siswa. Di samping itu juga dapat dilihat bahwa pada era global ini ada pergeseran paradigma belajar secara signifikan. Guru perlu memberikan pengalaman kepada siswa sebanyak mungkin dengan memanfaatkan berbagai lingkungan belajar yang mendukungnya agar guru bisa bergeser dari model transmisi ke model pembelajaran yang konstruktivis. Hasil akhir yang diharapkan dari model pembelajaran yang demikian adalah terciptanya motivasi para siswa untuk mau dan mampu melakukan belajar sepanjang hayat. Inilah hasil belajar yang amat penting pada diri siswa di era global. Mengapa begitu?. Karena perubahan yang begitu cepat, sehingga siapapun di era global harus terus menerus belajar. Artinya, belajar sepanjang hayat memang menjadi tuntutan hidup di era global. Untuk itu, guru harus memiliki daya inovasi yang tinggi dalam proses pembelajaran. Menjadi inovatif tidaklah mudah tanpa adanya upaya yang disengaja dan penuh kesadaran.

Menjadi pendidik (guru) di era desrupsi memiliki tantangan dan harapan besar dalam membangun bangsa ini. Mengingat pada satu abad Indonesia di tahun 2045, Indonesia memiliki bonus demografi yang hampir $70 \%$ dari jumlah penduduknya merupakan usia produktif. Mengajar di era global merupakan masa di mana terjadi revolusi digital yang sangat cepat. Peralihan generasi pendidik yang dirasakan saat ini begitu terasa. Di satu sisi perubahan teknologi digital yang sangat cepat yang mempengaruhi sistem pendidikan, tidak berbanding lurus dengan perubahan kemampuan guru dalam penguasaan teknologi dan multimedia dalam pembelajaran. Hal ini berdampak kepada lambannya alih teknologi pada proses pembelajaran. Pada sisi lain, siswa jauh lebih menguasai teknologi digital.

Cara yang paling bijak yang perlu dilakukan guru adalah dengan berkolaborasi, baik sesama kolega maupun bersama siswa dalam pemanfaatan teknologi dalam pembelajaran. Guru tidak boleh menganggap, bahwa dirinyalah yang paling pintar dan lebih. Guru tiidak boleh lagi sekedar memberi instruksi-instruksi. Tetapi guru harus mampu belajar dari siswanya, koleganya, dan belajar mandiri untuk penguasaan teknologi digital. Pengintegrasian teknologi digital yang modern dalam dunia pembelajaran saat ini bukan pilihan atau "barang mewah." Tetapi sesuatu keharusan yang perlu dilakukan guru. Jika tidak, maka bersiap-siaplah akan tertinggal oleh perubahan yang begitu cepat terjadi. Bahkan sebuah pendapat menyatakan, "Jika ingin menguasai dunia, maka kuasailah teknologi."

Tokoh pendidikan Prof. Arif Rahman, menyebutkan bahwa untuk menjadi guru yang profesional di Abad 21 (era global/desrupsi), selain harus menguasai teknologi digital, guru harus mengembangkan prinsip-prinsip: Disiplin: Guru garus memiliki disiplin berupa tanggung jawab terhadap tugasnya, ketepatan bekerja, keterikatan, keteraturan, dan kemampuan; Kemartabatan: Guru harus memiliki kejujuran, semangat juang, keberanian untuk benar-benar berlaku adil, kemuliaan/kepatuhan/keunggulan, ketekunan, dan tahan terhadap cobaan.

Hal yang tak kalah penting dihadapi oleh guru di era global sebagai tantangan dan harapan adalah soal kreativitas dan inovasi. Chen dalam Sofyan (2017: 3) 
mendefinisikan, bahwa inovasi merupakan suatu tradisi kita untuk terus membiasakan diri kita dan siswa untuk memiliki dorongan dan tekad dalam membuat perbedaan dalam masyarakat atau komunitasnya. Chen menegaskan dengan kata "tradisi" tentang suatu inovasi. Jika dianalisis lebih dalam, jika tidak dijadikan suatu budaya atau tradisi yang kuat, maka baik guru maupun siswa tidak akan memiliki dorongan dan tekad dalam membuat perbedaan-perbedaan dalam masyarakatnya. Dalam konteks ini, maka inovasi sebagai suatu budaya untuk menumbuhkan perubahan dengan tekad dan dorongan yang kuat harus menjadi budaya dengan pondasi yang kokoh yaitu karakter kerja keras, mandiri, bertanggung jawab, dan berbudi pekerti. Guru harus bisa menjadikan dirinya sebagai model "agent of change" dalam membangun karakter dan menciptakan kreativitas dan inovasi.

\section{4) Peran Guru dan Literasi Baru dan Revolusi Industri 4.0}

Saat ini kita tengah memasuki era revolusi industri 4.0, yaitu era dimana dunia industri digital telah menjadi suatu paradigma dan acuan dalam tatanan kehidupan saat ini. Era revolusi industri 4.0 hadir bersamaan dengan era disrupsi. Untuk menghadapi revolusi industri 4.0 atau era disrupsi diperlukan "literasi baru" selain literasi lama. Literasi lama yang ada saat ini digunakan sebagai modal untuk berkiprah di kehidupan masyarakat. Literasi lama mencakup kompetensi baca, tulis dan hitung (calistung). Sedangkan literasi baru mencakup literasi data, literasi teknologi dan literasi manusia.

Literasi data terkait dengan kemampuan membaca, menganalisis dan membuat konklusi berpikir berdasarkan data dan informasi (big data) yang diperoleh di dunia digital. Dengan adanya kemajuan internet, arus informasi dan data semakin hari semakin jauh berkembang, banyak informasi dan data yang ada di dunia digital belum tentu sahih dan benar, tetapi juga banyak yang mengandung informasi bohong dan manipulatif (hoax). Dalam konteks paedagogik, seorang guru harus mampu mengkonfirmasi dan mengklarifikasi sebuah informasi yang benar, baik itu itu disampaikan kepada anak didik, juga memberikan penjelasan yang benar terhadap informasi yang diperoleh oleh anak didik dalam proses pembelajaran. Literasi teknologi terkait dengan kemampuan memahami cara kerja mesin. Aplikasi teknologi dan bekerja berbasis produk teknologi untuk mendapatkan hasil maksimal. Penciri utama revolusi industri adalah pesatnya kemajuan teknologi yang mengarahkan kepada digantikannya tenaga manusia dengan mesin ataupun robot dengan mengandalkan kecerdasan buatan (Artificial Intelligence). Literasi manusia terkait dengan kemampuan komunikasi, kolaborasi, berpikir kritis, kreatif dan inovatif (4C). Stake holder pendidikan, dalam hal ini guru sebagai garda terdepan dalam proses pendidikan harus mampu mengembangkan kapasitas kognitif peserta didik, sehingga mampu memiliki kemampuan mental yang tinggi, berpikir kritis dan sistemik. Disamping itu peserta didik bisa memiliki jiwa kemanusiaan (humanities) yang baik.

Mencermati beberapa literasi baru di atas, untuk itu tugas dunia pendidikan saat ini melalui proses pembelajarannya bukan hanya menekankan pada penguatan kompetensi literasi lama, tetapi secara simultan mengokohkan pada penguatan literasi baru yang menyatu dalam penguatan kompetensi bidang keilmuan dan keahlian atau profesi. Dengan demikian perlu adanya reorientasi baru dalam penyelenggaraan pendidikan, baik pada pendidikan dasar, menengah dan tinggi. Agar dunia pendidikan tetap memiliki daya relevansi yang tinggi dalam era revolusi industri 4.0 atau era disrupsi, para pendidik (guru) dalam proses pembelajaran perlu mengintegrasi capaian pembelajaran dua bidang secara simultan dan terpadu, yaitu capaian bidang literasi lama dan literasi baru.

\section{SIMPULAN}

Disadari bahwa guru merupakan kunci utama keberhasilan proses pembelajaran di 
sekolah. Meskipun dalam era saat ini, guru bukanlah menjadi satu-satunya sumber belajar, tetapi peran guru sangat sentral dan strategis. Guru harus menjadi agen perubahan dalam pembelajaran siswa, sehingga siswa mengalami sendiri proses belajaranya. Oleh karena itu, harapan keberhasilan pendidikan sering dibebankan pada guru

Guru sebagai tenaga pendidik adalah pelaksana profesi kependidikan, dalam melaksanakan profesinya tersebut diperlukan beberapa persyaratan yang harus dipenuhi oleh seorang guru agar memiliki kualifikasi dan kredabilitas di bidang pendidikan. Hal ini menjadi syarat bagi terwujudnya guru yang profesional, yakni memiliki kompetensi secara menyeluruh baik dibidang ilmu kependidikan dan metedologi pembelajaran juga substansi bidang keilmuan. Suatu profesi yang dijalani akan semakin ketinggalan dan terpuruk jika tidak dilaksanakan secara profesional.

Guru akan menjadi profesi yang berkembang manakala terus menerus mengubah diri, karena praktis pendidikan akan terus berlangsung dalam situasi dan waktu yang berbeda. Suatu profesi yang berkembang adalah profesi yang terus menerus mengubah diri. Oleh karenanya guru harus terus mengembangkan dan meningkatkan kemampuannya bagi terjadinya perubahan pada dirinya dan dapat melakukan perubahan pada pelaksanaan tugas dan kewajibannya dalam pembelajaran. Kesempatan guru untuk mengembangkan diri sangat terbuka lebar tergantung pada kemauan dan kesiapan untuk melakukannya. Peningkatan kemampuan guru untuk menjalankan profesinya jangan bersikap pasif melainkan harus proaktif, jangan menunggu kesempatan melainkan mencari kesempatan. Jika guru sudah memiliki sikap seperti itu, maka ia akan selalu berusaha mengembangkan diri secara mandiri dalam kejamuan jaman selaras dengan era revolusi industri 4.0.

\section{DAFTAR PUSTAKA}

Agustian, Ary G. 2005. Rahasia Sukses Membangun Kecerdasan Emosional dan Spiritual (ESQ). Jakarta : ARGA

Arifin. 2009. Meningkatkan Peran Guru sebagai Agen of Change Pembelajaran SiswaTersedia pada: https://drarifin.wordpress.com/2009/0 9/16/29/

Atmadi, (ed). 2000. Transformasi Pendidikan Memasuki Milenium. Yogyakarta : Kanisius dan Unversitas Sanata Dharma.

Bochari, M. 1994. Ilmu Pendidikan dan Praktek Pendidikan Dalam Renungan. Jakarta: IKIP Muhammadiyah Jakarta Press.

Dantes, Nyoman. 2017. Pedagogik dalam Perspektif. Singaraja: Undiksha Press.

Djohar, 1999. Reformasi dan Masa Depan Pendidikan di Indonesia. IKIP. Yogyakarta

Fahri, Ahmad dkk. 2013. Tantangan Guru Masa Kini (Makalah). Jakarta : Tanpa penerbit

Giddens, A.. 2001. Runway World. Jakarta: PT Gramedia Pustaka Utama.

Hamzah.B.U., 2008. Model Pembelajaran. Menciptakan Proses Belajar Mengajar Yang Kreatif dan Efektif. Jakarta : PT. Bumi Aksara.

Jailani, M. Syahran. 2014. Guru Profesional dan Tantangan Dunia Pendidikan (Artikel). Jambi : IAIN Sulthan Thaha Saifuddin

Koentjaraningrat, 1982. Kebudayaan, Mentalitas dan Pembangunan. Jakarta : PT. Gramedia.

Nasution, 2006. Berbagai Pendekatan dalam Proses Belajar dan Mengajar. Jakarta : PT. Bumi Aksara

Oemar Hamalik. 2002. Pendidikan Guru Berdasarkan Pendekatan Kompetensi. Jakarta : Bumi Aksara.

Prayitno. 2008. Dasar Teori dan Praksis Pendidikan. Padang. UNP Press.

Samba, S. 2007. Lebih Baik Tidak Sekolah. Yogyakarta. LKIS. 
Sanjaya, W. 2007. Strategi Pembelajaran, Berorientasi Standar Proses Pendidikan. Jakarta : Kencana Prenada Media Group.

Seligman, Marttin.E.P. 2005. Authentic Happiness: Using the New Positive Psychology to Realize Your Potential For Lasting Fulfillment. Penerjemah. Eva Yulis. Authentic Happiness, Menciptakan Kebahagiaan dengan Psikologi Positif.Bandung : PT. Mizan Pustaka.

Soetjipto dan Kosasi R. 1999. Profesi Keguruan. Jakarta : PT. Rineka Cipta.

Sofyan. 2017. Menjadi Guru di Abad 21: (Tantangan Dan Harapan)(Makalah) Tersedia pada: https://www.academia.edu/32799413/ MENJADI_GURU_DI_ABAD_21_T antangan_and_Harapan.docx

Suparno, P. 2004. Guru Demokratis di Era Reformasi Pendidikan. Jakarta: Grasindo.

Supriadi, D. 2004. Satuan Biaya Pendididkan Dasar dan Menengah.
Rujukan bagi Penetapan Kebijakan Pembiayaan Pendidikan pada Era Otonomi dan Manajemen Berbasis Sekolah. Bandung : PT. Remaja Rosda Karya.

Surachmad, W. 2002. Implikasi Manajemen Pendidikan Nasional Dalam Konteks Otonomi Daerah (Makalah). Konaspi Jilid II. Jakarta : UNJ

Sztompka. 2004. The Sociology of Social Change. Diterjemahkan Alimandan. Sosiologi Perubahan Sosial. Jakarta : Prenada Media.

Tilaar, 2002. Membenahi Pendidikan Nasional. Jakarta : PT. Rineka Cipta.

Tilaar. H.A.R. 2002. Perubahan Sosial dan Pendidikan Pengantar Pedagogik Transformatif Untuk Indonesia. Jakarta : Grasindo.

Usman, M.U., 2000. Menjadi Guru Profesional.Bandung : PT. Remaja Rosda Karya.

Wahab, A.A., 2007. Metode dan ModelModel Mengajar Ilmu Pengetahuan Sosial. Bandung: Alfabeta. 